\title{
A Review on Determinants of Accounting Information System Adoption
}

\author{
Manchilot Tilahun \\ Department of Accounting and Finance, Raya University, Maichew, Ethiopia
}

Email address:

tilahunmanchilot@gmail.com

\section{To cite this article:}

Manchilot Tilahun. A Review on Determinants of Accounting Information System Adoption. Science Journal of Business and Management. Vol. 7, No. 1, 2019, pp. 17-22. doi: 10.11648/j.sjbm.20190701.13

Received: December 24, 2018; Accepted: January 24, 2019; Published: February 21, 2019

\begin{abstract}
The determinants of accounting information system adoption include the factors that affect the decision of to adopt or not accounting information system by organizations like human resource, performance expectancy, perceived ease of use, top management support, government support, etc. nowadays business firms and other organizations are tending to adopt and implement accounting information system since the adoption of accounting information system have advantages of increasing functionality of accounting departments within the organization, improved accuracy, faster processing which aids companies to better cost control and enable companies to have a better external financial reporting. The objective of this study is to identify the major determinants accounting information system adoption by companies and firms throughout the world. Also the study have found that management support and commitment, perceived ease of use, performance expectancy, availability of human resource and government support are the major factors that influence the adoption of accounting information system. Those conducted previous researches in different countries have recommended that management of organizations should have to support the implementation of accounting information system, higher education institutions to come up with appropriate curriculum and department to provide qualified graduates for the employers and the government to support accounting information system adoption by giving incentives and granting access to finance for firms.
\end{abstract}

Keywords: Accounting Information System, Accounting Information System Adoption, Government Support, Perceived Ease of Use, Performance Expectancy

\section{Introduction}

Accounting is the information system that measures business activity, processes the information into reports, and communicates the results to decision makers. Accounting is "the language of business." If this is the case, then an accounting information system is the intelligence or the information providing vehicle of that language. Accounting information system is a system that gathers, records, stores, and processes data to produce information for decision makers [1].

An accounting information system can be either manual system or a computerized system that use information technology or something in between. The procedure is the same without regarding the approach taken. Accounting information system must gather, enter, process, store and report financial information. The manual or computer hardware and software are the tools used to produce the information [1].

Accounting information system is a subsystem of organizational management information systems. The purpose of the accounting information system is to measure financial performance of a business organization and performing organizational accounting functions. Accounting information is required not only by management in managing the financial activities of the companies but also by shareholders, who need regular financial statement in order to evaluate business performance. It is required by a government to ensure the effective utilization the country's resources therefore; it plays a significant role in all economic and social aspects. It also assists auditing and examining irregularities and misappropriations [2].

With the global integration of goods and services, markets and competition, businesses need to be more effective, flexible, offer enhanced quality products and services, reduce cost and be timelier in meeting customer's needs. Accounting 
information systems provide essential resources in order to meet these requirements effectively [3].

Accounting information has a great potential to have an impact on enterprise's performance. Extensive use of accounting information system is used to make financial and managerial decisions of the firm. In developing countries, these decisions are highly expensive which leads to annual loss of millions or billions of dollars when such decisions are made poorly. Therefore, it is essential for financial decision making to correctly guided by improving quality of information system through the use of accounting information system which gives a competitive edge to enterprises and improving their organizational performance [4].

The accounting information system is considered as a requirement in the small and medium-size organization in which massive amount of information is required to perform the level of performance [5]. Using new technology such as accounting information system have a more significant benefit for businesses in which the accounting information system give job satisfaction and keep the enterprise survive [6].

Generally, businesses have received a huge demand to improve information processing capacity because of the need for high amount of information responses to enable information system in boosting up performance. Accounting information system could help small and medium enterprises to control short-term issues in areas of expenditure, costing and cash stream by offering information to assist, control and monitoring [7]. Technology innovation directly and indirectly affects small and medium enterprises performance [4]. Information system technology is increasingly becoming significant in public service to render services of high quality for large as well as small business organizations [8]. many of problems of organizations problems could be solved by moving from manual information system to a more advanced system such as adopting accounting information system, in order to overcome the increased volume of business transactions and high demand of useful information [3].

Despite all the advantages associated with the use of accounting information system, a number of businesses and organizations faced the risk of failure in adopting it due to lack of infrastructure, poor electricity supply [9], lack of commitment, difficulty of obtaining suitable hardware and soft ware, lack of skilled personnel [10], management inability and poor management $[11,12]$, lack of resources [4], Lack of capital [13].

This paper will have a great contribution to the academic literature by directing researchers in the area of accounting information system to examine the results of previous studies to find relationships among accounting information system adoption and implementation with its factors.

\section{Methodology of the Study}

The factors that have an effect on the adoption of accounting information system has been studied by a number of studies conducted by adopting different research methods analytical methods. The studies included in this review were identified carefully in a systematic process that is conducted across the globe in different periods of time. The researcher has tried to identify a number of researches conducted on the issue of accounting information system adoption and its determinant factors. Studies that are conducted by using accounting information system adoption as a dependent variable were found to be relevant for this review. The study has identified and considered that accounting information system adoption is expressed as a function of a number of explanatory variables like human resource, management commitment, perceived ease of use, government support and performance expectancy. In doing so a statistical technique which is called Meta analysis was applied for combining the findings from a number of independent studies on the same issue.

\section{Accounting Information System}

While accounting is a business function which aims to provide specific users with quantitative accounting information, the accounting information system is an information system that is adopted and implemented within an organization to enable the accomplishment of accounting functions $[14,15]$. There are various definitions of accounting information system. It can be viewed as an established structure system within a business firm, which uses financial resources and other resources to transform economic data into accounting information for the purpose of satisfying the information needs to a variety of users. Accounting information system consists of four major subsystems namely: The transaction processing system, financial reporting system, fixed asset system and the management reporting system which provides information for internal users [15].

Accounting information system can be defined as a system that processes data and transactions to provide financial information to interested users (both internal and external users) who needs to plan, control and operate their businesses and organizations [16].

Accounting Information System can be defined as a computer-based electronic system used for collecting, storing, processing and communicating financial and accounting data through financial statements with the aim of supporting and guiding organizational decision making process [17].

\subsection{Importance of AIS Adoption}

Accounting information system can be defined as a system that processes data and economic transactions to provide users with information, whom need to plan, control and operate their businesses [18]. Here, accounting information system is viewed as a system that helps management in planning and controlling processes by providing relevant and reliable information for decision making. It suggests that Accounting information system's functions are not only 
producing financial reports. Its role goes beyond this traditional perspective. Accounting information system should be utilized to include planning and managing business activities. It could also be used as a controlling mechanism such as budgeting. Therefore, full adoption of the system is essential to fully attain the system's benefits.

Information system adoption did increase companies' performances and operations efficiency especially in large companies and as well good management of resources and better control of expenditure, budgeting and forecasting enhance the wellbeing of company [18]. Accounting information systems also provide information on both actual and budgeted data which would help companies to establish, plan and control operations [19].

The use of accounting information system played an important role which contributes to company's value added by providing internally generated financial statements that would help the company to make better strategic plan [20].

Accounting information system is a subsystem of organizational management information systems. The intended usage of accounting information system is to measure business financial performance and perform organizational accounting functions. Accounting information system can be simply defined as a computer based system usually used for identifying, collecting, recording and analyzing a company's financial data. Accounting information systems are generally used by managers to make strategic actions and decisions, and provide financial reports for external users [21].

accounting information systems have a number of advantages, such as enhancing business processing efficiency, better financial report, greater flexibility in information generation, eliminating duplications, upgrading integration of financial reports and forms, reduced paperwork and cost, and rationalized decision making process by providing an accurate accounting information [22].

According to [15], the advantages of computerized accounting information system can be summarized as follows:

i. Increased Functionality

Computerized accounting systems have also improved the functionality of accounting departments by increasing the timeliness of accounting information. By improving the timeliness of financial information, accountants can prepare reports and operations analyses that give management an accurate picture of current operations. The number of financial reports has also been improved by computerized systems; cash flow statements, departmental profit and loss, and market share reports are now more accessible with computerized systems.

\section{ii. Improved accuracy}

Most computerized accounting systems have internal check and balance measures to ensure that all transactions and accounts are properly balanced before financial statements are prepared. Computerized systems also don't allow journal entries to be out of balance when posting, ensuring that individual transactions are properly recorded.
Accuracy is also improved by limiting the number of accountants that have access to financial information. Less access by accountants ensures that financial information is adjusted only by qualified supervisors.

\section{iii. Faster processing}

Computerized accounting systems allow accountants to process large amounts of financial information and process it quickly through the accounting system. Quicker processing times for individual transactions has also lessened the amount of time needed to close out each accounting period. Monthor year-end closing periods can be especially taxing on accounting departments, resulting in longer hours and higher labor expense. Shortening this time period aids companies in cost control, which increases overall company efficiency.

\section{iv. Better external reporting}

Financial statements prepared to investors and stakeholders have been improved by computerized accounting systems. Improved reporting allows investors to determine if a company is a good investment for growth opportunities and has the potential to be a high-value company. Companies can utilize these investors for equity financing, which they use for expanding.

\subsection{Factors Affecting Accounting Information System Adoption/Implementation}

Researchers have stated that adoption of accounting information system can be determined by a number of independent or explanatory variables like chief executive officer innovativeness, management commitment, and perceived ease of use, human resource and perceived complexity of accounting information system. This section will explain the determinant factors of accounting information system adoption as suggested in previous researches.

\subsubsection{Human Resource}

Human resources are most likely to be core sources of continuous competitive advantage of organizations [23]. There is a positive relationship between human resource and adoption of accounting information system in the hospitals of Jordan [24]. Another study have found that quality of accounting personals is an important factor in the adoption and implementation of accounting information system [25]. There is a significant correlation between human resource and intention to adopt computerized accounting information system [26]. Lack of skilled personnel is the main problem for small businesses not to adopt information technology in Canada [27].

\subsubsection{Management Commitment}

Management commitment is very essential since without commitment of top management implementation of many information system projects will fail. This is because management is a noteworthy supporter of information system implementation in terms of guaranteeing the availability of resources, human resources and visibility of system implementation [28]. If there is low level of top management 
support then top management may not involved in aspects of information system implementation [29]. They found that management commitment improve the effectiveness of information system implementation, because they provide the resources needed for information system projects. Similarly, management commitment has adequate effect on accounting information system implementation [30]. Additionally, top management support and commitment are the most significant variable which is continuously found to be an important factor in accounting information system adoption [31]. Another study has found that top management support is a significant factor to accounting information system implementation [32]. Top management support and commitment is the most influential and significant organizational factor in the adoption and implementation of e-commerce by Demark and Australian companies [33]. a study on the perception of Utara Universiti Malaysia students about factors that affect Accounting information system implementation and information quality and found that management commitment has a positive significant impact on the implementation of accounting information system and recommends that management should support accounting information system implementation and ensuring adequate resources and comprehensive training to accountants [34]. Another study conducted by [35] found that management commitment has a great impact on accounting information system usage. They suggest that firms with higher level of management commitment have greater extent for accounting information system usage. In a study conducted by [36] management commitment was found to have a positive significant impact on accounting information system usage in Indonesia which implies that with a high organizational commitment, the employees trust in the organizations objectives so that they will have a positive perception of the system implementation.

\subsubsection{Perceived Ease of Use}

According to [37], perceived ease of use means the user perceived that the system is very simple to use. Therefore, it is believed that users' behavioral intention to use the system increases when system is perceived not difficult to use. Users that perceive accounting information systems to be easy to use are more likely to adopt the technology than those that do not. Perceived ease of use is one of the most important factors in explaining accounting information technology adoption [38]. Similarly, perceived ease of use has a significant effect on the intention to use information systems [39]. A result of a study conducted by [36] in Indonesia indicates that perception of a system to use and system adoption have a positive relationship which implies that an organization with employees which have high perception of ease of use are motivated to use accounting information system to improve their performance in congruence with organizational objectives. On the other hand there is no significant relationship between perception of a system as simple to use and behavioral intention to adopt and use it [40]. In line with this there a study that found the effects of perceived ease of use on information system adoption was insignificant in United Arab Emirates [41].

\subsubsection{Government Support}

Government support refers to the authority assistance and determination to encourage and motivate organizations to adopt and use accounting information system and spread over among them [42]. A study conducted in Ethiopia by adopting a cross sectional survey research design to identify the factors for accounting information system adoption among small and medium enterprises has found that government support is the main determining factor in accounting information system adoption. In addition he recommends that the government should support manufacturing enterprises in terms of allowing access to finance, capacity building trainings, provision of information communication technology infrastructures, and provide incentives for the adoption of accounting information system technologies [43]. Another study conducted has found that government support was among the factors that significantly affect the usage of accounting information systems by Jordanian small and medium enterprises [35].

A study conducted in Zimbabwe by adopting a descriptive research design tried to identify the factors for non adoption of accounting information system by small and medium enterprises and have found that lack of government support is among the factors for non adoption of accounting information system. They also recommend that government through the ministry of information and communication technology, should ensure that it provide easy access to computerized accounting information systems through financing the purchasing of equipments and infrastructures for computerized accounting information system for small and medium enterprises and by providing incentives for those small and medium enterprises that purchase accounting information systems [44].

\subsubsection{Performance Expectancy}

Perceived usefulness or performance expectancy is the extent to which users of a system are optimistic that their productivity and effectiveness could be improved through the use of a system [45]. Users' intention to adopt a system is determined by the perception of usefulness they have on the system [46]. The findings of a research conducted found that perceived usefulness is a factor that influences behavioral intention to adopt accounting information system in most of the organizations [47]. Performance expectancy had significant influence on the behavioral intention to use accounting information system by small and medium sized enterprises in Sri Lanka which suggests that if the entrepreneurs' realize the benefits in their performance gained from using accounting information system, more of them will adopt the system[48]. In Australia, there is a finding that performance expectancy have an important impact on the decision to use accounting information system which implies that if accounting practitioners perceive accounting information system as useful, they are more likely to use accounting information system [49]. On the other 
hand, performance expectancy is an insignificant factor in the adoption of the accounting information system by accountants in Libya [50].

\section{Conclusion}

Accounting information system is a computer-based system that processes financial information and supports decision tasks in the context of coordination and control of organizational activities. Accounting information system provides information which can be used in the process of planning and managing business activities of an organization. Additionally, the adoption of accounting information system have advantages of having greater flexibility in information generation, increases company's performance and operational efficiency, providing accurate and timely information and to have a better external reporting. In this study the previous researches on the determinants of adoption of accounting information system were discussed briefly.

The findings of may researches suggests that users who perceive accounting information system as simple to use have higher tendency to adopt it and availability of qualified and skilled manpower as well as performance expectancy can affect the intention to adopt accounting information system. Reviews of previous studies have also showed that businesses and organizations need government support and top management commitment and support to adopt and implement accounting information system. Since accounting information system is an information providing vehicle for individuals and organizations that are in a need of it in order to make their decisions regarding their businesses and organizations, it is important to understand the factors for its adoption.

\section{References}

[1] Romney, M., \& Steinbart, P. (2012). Accounting information systems, $12^{\text {th }}$ ed.

[2] Ahmad, A., Rand, A., \&Raed, M. (2016). Interrelated Factors Influencing the Adoption Decision of AIS Applications by SMEs in Jordan. International Business Research, 9 (10), 4662 .

[3] Smith, J., \& Puasa, P. (2016). Critical factors of Accounting Information Systems (AIS) effectiveness: A qualitative study of the Malaysian federal government qualitative study of the Malaysian federal government. Proceedings of the $\mathrm{Br}$. Account Finance Association Annual Conference 2016, March 21-23, 2016, University of Bath, Somerset, UK.

[4] Soto-Acosta, Popa, P., \& Palacios-Marques, D. (2015). Ebusiness, organizational innovation and firm performance in manufacturing SMEs: An empirical study in Spain. Technol. Econ. Dev. Econ., 22, 885-904.

[5] Ismail, A.\& King, M. (2007). Factors influencing the alignment of accounting information systems in small and medium sized Malaysian manufacturing firms. Journal of Information System and Small Business, 1, (1-20).
[6] Aziz, K. (2003). Accounting information system satisfaction and job satisfaction among Malaysian accountants. Proceedings of the Pacific Asia Conference on Information Systems, Volume 54, December 2003, AIS Electronic Library.

[7] Ismail, A., \&Zin, R. (2009). Usage of accounting information among Malaysian Bumiputra small and medium nonmanufacturing firms.J. Enterprise Resour. Plan. Stud.

[8] Jacobsen, I.(2018). Adopting and refining e-services-The role of organization size. Public Organization Review, 18, 111-123.

[9] Malik, S., \& Khan, E (2009). Implementation of an Electronic Hospital Information System in a Developing country: A case study of Pakistan, mastersDissertationAmnaan University.

[10] Ismail, A. (2010). The Impact of Information Technology on Performance: The Mediating Role of Management Accounting Systems.

[11] Alnajjar, M. (2016). Impact of accounting information system on organizational performance: A study of small and midsized enterprises in UAE. International journal of accounting research, 4.

[12] Meiryani, J. (2014). Influence of Top Management Support on the Quality of Accounting Information System and Its Impact on the Quality of Accounting Information. Research Journal of Finance and Accounting, 5 (11), 124-132.

[13] Harash, E., Al-Timimi, S.,\&Radhi, A. (2014). The influence o f Accounting Information Systems (AIS) on performance of Small and Medium Enterprises (SMEs) in Iraq. Journal of business management, 3, 48-57.

[14] Borthick, A., \& Clark, R. (1990).Making Accounting Information Systems Work: An Empirical Investigation of the Creative Thinking Paradigm..Journal of Information Systems, $4(3), 48-62$.

[15] Ghasemi, M., Shafeiepour, V., Aslani, M., \&Barvayeh, E. (2011).The Impact of Information Technology (IT) on Modern Accounting Systems.Procedia-Social and Behavioral Sciences, 28, 112-116.

[16] Emad, H., Suhail A., \& Ahmed, R. (2014). The Influence of Accounting Information Systems (AIS) on Performance of Small and Medium Enterprises (SMEs) in Iraq.Journal of business and management, 3 (4), 48-57.

[17] Romney, B., Steinbart, P., \& Cushing, B. (1997).Accounting Information System. Seventh Edition, Addison-Wesley.

[18] Saira, K., Zariyawati, A., \&Annuar, N. (2010). Information system and firms' performance: the case of Malaysian small medium enterprises. International business research, 3 (4), 28.

[19] Grande, E., Estebanez, R., \&Colomina, C. (2010). The impact of Accounting Information Systems (AIS)on performance measures: empirical evidence in Spanish SMEs. The International Journal of DigitalAccounting Research, 11 (11), $25-43$.

[20] Sori, M.(2009). Accounting Information Systems (AIS) and Knowledge Management: A Case Study. American Journal of Scientific Research, 4, 36-44.

[21] Rom, A., \& Rohde, C. (2007). Management Accounting and Integrated Information Systems: A Literature Review. International Journal of Accounting Information Systems, 8 , 40-68. 
[22] Booth, P., Matolcsy, Z., \&Wieder, B. (2000). The Impacts of Enterprise Resource Planning Systems on Accounting Practice: The Australian Experience. The Australian Accounting Review, 10 (3), 4-18.

[23] Barney, B., \& Wright, M. (1998).On becoming a strategic partner: the role of human resources in gaining competitive advantage. Human Resource management,37 (1),31-46.

[24] ALshbiel, O., Al-Awaqleh, A. (2011).Factors affecting the Applicability of the Computerized Accounting System. International Research Journal of Finance and Economics, Issue 64.

[25] Zhou, L. (2010). The Research on Issue and Countermeasures of Accounting Information of

[26] Ahmad, A., Mohammad, H., Nik, K., \&Jamal, M. (2013).Factors that Affect Accounting Information System Implementation and Accounting Information Quality: A Survey in University Utara Malaysia. American journal of Economics, 3 (1), 27-31.

[27] Gibson, N., Holland, P., \& Light, B. (2000). Enterprise Resource Planning: A Business Approach to Systems Development.32nd Hawaii International Conference on System Sciences, Maui, HI, IEEE Computer Society Press, Los Alamitos.

[28] Schwalbe, K. (2006). Introduction to Project Management: Course technology, Thomson Learning. Inc. Cengage Learning, Inc., Boston, Massachussetts, USA.

[29] Thong, Y., Chee-Sing, Y., \& Raman, S. (1996), Top management support, external expertise and information systems implementation in small businesses. Information Systems Research, 7 (2), 248-267.

[30] Rahayu, K. (2012). The factors that support the implementation of accounting information system: A survey in Bandung and Jakarta's taxpayer offices, Journal of global management.

[31] Ramdani, B., Kawalek, P.,\& Lorenzo, O. (2009).Predicting SMEs' adoption of enterprise systems. Enterprise Information Management, 22, 10-24.

[32] Komala, A.R., 2012. The influence of the accounting managers' knowledge and the top managements' support on the accounting information system and its impact on the quality of accounting information: A case of zakat institutions in Bandung. Journal of global management, 4, 53-73.

[33] Scupola, A. (2009). SMEs' e-commerce adoption: Perspectives from Denmark and Australia. Journal of Enterprise Information Management, 22 (12), 152-166.

[34] Ahmad, A., Rand, A., \& Raed, M. (2013).Interrelated Factors Influencing the Adoption Decision of AIS Applications by SMEs in Jordan. International Business Research, 9 (10), 4662.

[35] Lutfi, A., Idris, K., \& Mohammad, R. (2016).The Influence of Technological, Organizational and Environmental Factors on AIS Usage among Jordanian SMEs. International Journal of Economics and Financial Issues, 6 (7), 240-248.

[36] Azmi, F., \& Sri, M. (2015). Factors that affect accounting information system success and its implication on accounting information quality. Asian journal of information technology,14 (5), 154-161.
[37] Muhammad, K., Siti, S., \&Aidi, A. (2017). The influence of Perceived Usefulness and Perceived Ease of Use on the Continuous Intention to Use Electronic Collection System in Nigerian Hospitals: A Conceptual Approach. Asian Journal of Multidisciplinary Studies, 5 (6), 225-229.

[38] Legrisa, A. (2003). Perceived usefulness, perceived ease of use, and user acceptance of information technology.MIS Quarterly 13 (3), 319-340.

[39] David, G., \&Detmar, S. (2000). The Relative Importance of Perceived Ease of Use in IS Adoption: A Study of ECommerce Adoption. Journal of the association for information systems, 1 (8), 1-28.

[40] Nasri, W. \& Charfeddine, L. (2012). Factors affecting the adoption of internet banking in Tunisia: an integration theory of acceptance model and theory of planned behavior, Journal of high technology management research, 23 (1); 1-14.

[41] Samar, M. (2009). Investigating the Factors Influencing Customers' Adoption of Online Banking in the United Arab Emirates. Journal of international technology and information management, 18 (3), 361-184.

[42] Haithami, K., Khairul,A., Ruhanita, M., Yusasniza, Y., \&Daewud, M. (2019). Review Article Enterprises Performance Based Accounting Information System: Success Factors. Asian journal of scientific research, 1-12.

[43] Abera, A. (2018). Determinants of accounting information systems adoption in Ethiopia: Empirical evidence from large and medium manufacturing enterprises in Addis Ababa. International Journal of Applied Research, 4, 4-12.

[44] Gwangwava, E., Chinhoyi, R., \&Faitira, M. (2012). Evaluation of Factors Influencing Adoption of Accounting Information System by SME in Chenoa. Interdisciplinary Journal of Contemporary Research in Business, 4 (6), 11261136.

[45] Mou, J., Shin, H., \& Cohen, J. (2017). Understanding trust and perceived usefulness in the consumer acceptance of an eservice: a longitudinal investigation. Behavior and information technology, 6, 125-129.

[46] Sharma, D., \&Yadav, R. (2011). An empirical study on taxpayer's attitude towards e-return filing in India. International journal of research in computer application and management, 1 (6), 20-24.

[47] Diatmika, W., Irianto, G., \&Bardiwan, Z. (2016). Determinants of behavior intention of AIS based information technology acceptance. Imperial journal of interdisciplinary research, 2 (8), 125-138.

[48] Samsudeen, N., \&Aliyar, S. (2015). Evaluating the Intention to use Accounting Information Systems by Small and Medium Sized Enterpreneurs. Research journal of finance and accounting, 6 (22), 38-48.

[49] Chadi, A., Savanid, V., \&Yanning, L. (2010).AIS in Australia: UTAUT application \& cultural implication. 21 $1^{\text {st }}$ Australasian Conference on Information Systems.

[50] Adel, A., William, Y., Matthew, W., \& Scott, S. (2015). An Empirical Study of Factors Influencing Accounting Information Systems Adoption. Association for Information Systems, Completed Research Papers. Paper 3. 